\title{
INTERLEUKIN 18 GENE PROMOTER POLYMORPHISMS IN LATVIAN PATIENTS WITH RHEUMATOID ARTHRITIS
}

\author{
Anna Mihailova*, Helena Mikažāne*, Jānis Kloviṇs ${ }^{\star \star}$, and Liene N̦ikitina-Zaḳe** \\ * Rīga Eastern University Hospital, Linezera iela 6, LV-1006, Rīga, LATVIA, \\ e-mail: annamihailova@inbox.Iv \\ ** Biomedical Research and Study Centre, Rātsupītes iela 1, LV-1067, Rīga, LATVIA
}

Contributed by Jānis Kloviṇš

\begin{abstract}
Interleukin 18 (IL-18) is a proinflammatory cytokine involved in the pathogenesis of rheumatoid arthritis (RA). There are controversial reports suggesting that IL-18 promoter polymorphisms may be an independent marker of RA susceptibility. The aim of the present study was to determine whether polymorphisms of the IL-18 gene promoter in positions -607 (rs 1946519) and -656 (rs 1946518) are associated with RA, and its characteristics in the Latvian population. We examined 105 patients with RA diagnosed according to the criteria of the American College of Rheumatology. DNA and phenotypic data from a healthy control population was obtained from Genome Database of Latvian Population. Genotypes were obtained by direct sequencing. Single-nucleotide polymorphisms (SNPS) were studied and frequencies of alleles and genotypes were compared between patients and controls. A P value less than 0.05 was accepted as statistically significant. There were no significant differences in the distribution of alleles and genotypes between RA patients and the control group. The frequencies of IL-18-607C/A and -656G/T genotypes differed between patients and the control group in women $(\mathrm{P}=0.084$ and 0.097). Heterozygous genotypes -607CA and -656GT occurred more frequently in the RA group than in the control $(\mathrm{P}=0.046, \mathrm{P}=0.060)$, and this difference was also significant for the only women groups $(\mathrm{P}=$ $0.041, \mathrm{P}=0.054)$. The heterozygous states $-607 \mathrm{CA}$ and $-656 \mathrm{GT}$ of IL-18 gene affect susceptibility to $R A$. On the basis of investigated IL-18 polymorphisms, female patients with RA seem to represent a separate disease subgroup.
\end{abstract}

Key words: $R A, I L-18, S N P$, susceptibility, genetics.

\section{INTRODUCTION}

Rheumatoid arthritis (RA) is a systemic inflammatory disease, characterised by chronic synovitis and progressive joint destruction. The etiology of RA is multifactorial and includes a significant genetic component. Cytokines act as mediators of immune and inflammatory responses and play an important role in the pathophysiology of joint inflammation and destruction (Feldmann et al., 1996). A central feature of RA is a relative imbalance of cytokine production with a relative excess of proinflammatory molecules, compared with antiinflammatory mediators (Feldmann et al., 1996). It has been observed that the production of proinflammatory cytokines is markedly increased in serum and synovial fluid in RA patients. The expression levels of cytokines have a genetic background. Single nucleotide polymorphisms (SNPs), the most common genetic variations that have been identified in the cytokine genes promoter, may be responsible for variations in cytokine production. The successful therapeutic use of inhibitors of proinflammatory cytokines (TNF- $\alpha$, IL-6) underlines the importance of these molecules in driving rheumatoid inflammation and tissue damage. However, non-responder or partial responder patients are not uncommon, and inflammatory disease can flare on discontinuation of treatment. Therefore, new therapeutic targets in RA should be investigated.

Interleukin 18 (IL-18), a member of the IL-1 superfamily, was first identified as an interferon- $\gamma$ (IFN- $\gamma$ ) inducing factor (Okamura et al., 1995). It is widely expressed in human tissues (Dinarello et al., 1998). IL-18 in RA is produced predominantly by tissue macrophages (Gracie et al., 1999; Tanaka et al., 2001; Yamamura et al., 2001). In addition, mature IL-18 may also be released from dendritic cells (Gardella et al., 1999), neutrophils (Westphal et al., 2006) and endothelial cells (Yamaoka-Tojo et al., 2003).

IL-18 has a highly diverse range of biological function. IL-18 induces the synthesis of TNF- $\alpha$, granulocyte-macrophage colony stimulating factor, nitric oxide, and chemokines by $\mathrm{T}$ cells and natural killer cells (Dinarello, 1999). IL-18 directly activates synovial macrophages, promotes 
production of proinflammatory cytokines such as TNF- $\alpha$ and IL-1 $\beta$ (Gracie et al., 1999), induces the production of hemokines and expression of adhesion molecules by synovial fibroblasts (Morel et al., 2001; 2002), and stimulates angiogenesis (Park et al., 2001). IL18 indirectly stimulates osteoklastogenesis through upregulation of membrane bound receptor activator of NFkB ligand (RANKL) production from RA synovial $\mathrm{T}$ cells or through induction of TNF- $\alpha$, IL-1 $\beta$ and IL-6 (Dai et al., 2004).

IL-18 has been found in synovial tissue, and enhanced levels of IL-18 were observed in the serum and in the joint of RA patients (Gracie et al., 1999). Serum and synovial fluid IL-18 levels as well as synovial tissue IL-18 expression were correlated with disease activity parameters (erythrocyte sedimentation rate (ESR), serum C-reactive protein (CRP), and Disease Activity Score (DAS 28) ) (Yamamura et al., 2001; Joosten et al., 2003; Rooney et al., 2004; Petrovic-Rackov et al., 2006).

The $I L-18$ gene maps to chromosome 11q22.2-q22.3 (Nolan et al., 1998). Several single-nucleotide polymorphisms (SNPs) in the promoter region in the $I L-18$ gene are present, which may affect IL-18 expression. Allelic variants of cytokine genes associated with promoter gene region polymorphisms do not influence the protein amino acid sequence but can result in changes of cytokine production. The -607 C/A SNP is located at the binding sites for CREB transcriptional factors (cAMP response-element binding proteins), and therefore, mutations at this site can influence IL-18 expression and change the production of the cytokine (Giedraitis et al., 2001).

The aim of the present study was to examine two $I L-18$ gene SNPs in positions -607 (rs 1946519) and -656 (rs 1946518 ) in the promoter region in relation to the RA susceptibility, activity and severity.

\section{MATERIALS AND METHODS}

Patient population. A total of 105 patients with established RA (women and men) according to the well-known revised criteria of the American College of Rheumatology (ACR) for RA (Arnett et al., 1988) were consecutively recruited into the study during a one-year period. Patients with RA were recruited from the outpatient and inpatient populations in the Rheumatology Department Clinic "Linezers", Rīga Eastern Hospital, Latvia. Informed consent was obtained from all patients.

Evaluation of the patients included a physical examination with a particular focus on the pattern of joint involvement and laboratory analyses. The following data were obtained from the RA patients: age of disease onset, number of tender (TEN) and swollen (SW) joints, visual analogue scale (VAS) of pain and disease activity, physician assessment of disease activity, presence and value of rheumatoid factor (RF) and anti-cyclic-citrullinated peptides (antiCCP) antibodies, C-reactive protein (CRP), erythrocyte sedimentation rate (ESR), and rentgenological (RTG) stage. The modified disease activity score DAS28 was calculated as described (Prevoo et al., 1995). Simple X-rays of the hands and feet were analysed using the Steinbrocker method (Pincus et al., 1997). Within the RA group, eight patients lacked evidence of joint erosions on the radiograph (stage I: nonerosive RA) and 97 patients had erosions (stages II-IV: erosive RA; 19 stage II, 75 - stage III, and 3 - stage IV). Demographic, clinical, and laboratory characteristics of RA patients are summarised in Table 1.

A total of 242 healthy subjects with similar age and sex distribution were available for the study from Genome Database of Latvian Population (median 53, range 17-84 years, female $195(81.3 \%)$, male $45(18.8 \%))$.

Genetic analysis. Genotypes were obtained by direct sequencing. Analysis of SNPs at the -607 and -656 positions of the $I L-18$ gene were studied.

Genomic DNA was extracted from peripheral blood samples using the standard phenol-chloroform extraction method. The ILI8 promoter region harbouring SNPs at positions -607 and -656 was PCR amplified using forward 5'ATTCAGGACTTCCCCTTCCT-3' and reverse 5'CACTCTGCTCTTCAAACGTTACAT -3' primers. Amplicons were then purified using Sap-ExoI protocol and the sequences were obtained by direct sequencing of amplified products using forward PCR primer on a 3100 ABI prism DNA sequencer (Applied Biosystems).

Table 1

DEMOGRAPHIC, CLINICAL AND LABORATORY CHARACTERISTICS OF PATIENTS WITH RHEUMATOID ARTHRITIS

\begin{tabular}{lc}
\hline \multicolumn{1}{c}{ Characteristics } & $\begin{array}{c}\text { RA patients, } \\
\mathrm{n}=105\end{array}$ \\
\hline Age (years) & $58(26-83)$ \\
Female sex (\%) & $89(84.8)$ \\
Male sex (\%) & $16(15.2)$ \\
RA onset & \\
before 50 y.o. & $47(44.8)$ \\
after 50 y.o. & $58(55.2)$ \\
Disease duration (years) & $4.7(0.1-49.4)$ \\
Swollen joint count (28) & $6(0-20)$ \\
Tender joint count (28) & $8(0-26)$ \\
VAS pain (mm) & $49(1-97)$ \\
VAS disease activity (mm) & $50(2-93)$ \\
VAS physician's assessment (mm) & $34(4-89)$ \\
ESR (mm/h) & $26(2-76)$ \\
CRP (mg/l) & $6.90(0.00-113.4)$ \\
DAS28 (ESR) & $5.04(0.93-7.77)$ \\
DAS28 (CRP) & $4.5(1.84-7.6)$ \\
Rheumatoid factor positivity & $79(76.7)$ \\
Rheumatoid factor negativity & $24(23.3)$ \\
AntiCCP positivity & $58(79.6)$ \\
AntiCCP negativity & $15(20.6)$ \\
&
\end{tabular}

Values are given as medians (range) or as number (\%) 
The following PCR mix and conditions were used. PCR mix per sample contained $15 \mathrm{mkl}$ of 2x PCR Master Mix (Fermentas Life Sciences, Lithuania), forward and reverse primers $(1 \mathrm{mM})$ and $28 \mathrm{ng}$ of dried genomic DNA. The cycling conditions for PCR were: 5 minutes of initial denaturation at $95{ }^{\circ} \mathrm{C}$, followed by 32 cycles of 15 seconds at $95{ }^{\circ} \mathrm{C}, 30$ seconds at $56{ }^{\circ} \mathrm{C}, 30$ seconds at $72{ }^{\circ} \mathrm{C}$, and final extension for 10 minutes at $72{ }^{\circ} \mathrm{C}$.

Statistical analysis. The chi-squared test was used for the calculation of the deviation from the Hardy-Weinberg equilibrium. Fisher's exact test and chi-square tests was used to examine allele/genotype association with presence of RA and other qualitative variables (positive RF, anti CCP and others). Dichotomised variables were created for RF and anti- CCP levels (for RF positivity $14 \mathrm{IU} / \mathrm{ml}$; for antiCCP positivity $>5.0$ units $/ \mathrm{ml}$ ). ANOVA tests was used to compare quantitative variables (age at onset of RA, VAS, DAS28, SW28, TEN28, CRP, ESR) between genotype-stratified subgroups of RA patients. A $P$ value less than 0.05 was considered statistically significant. Odds ratios (OR) were calculated with a $95 \%$ confidence interval (CI). All statistics were conducted using the software package SPSS, version 13.0.

\section{RESULTS}

All genotyping results fit Hardy-Weinberg equilibrium. The distribution of alleles and genotypes is shown in Table 2.

There were no significant differences in the distribution of the $I L-18$ gene alleles and genotypes between RA patients and the control group, but we found a difference in the frequencies of IL-18-607C/A and -656G/T genotypes, not alleles, between RA patients and the control group in women (Table 3).

We found a significant difference between frequencies of heterozygous versus homozygous genotypes; heterozygous genotypes -607CA and -656GT occurred more frequently in the RA group than in the control (Table 4). This difference was even larger when only women were considered (Table $5)$.

There were no differences in marker distributions between RA patients and the control for different age groups, men and control groups (data not shown). There were no differences found between age of onset RA, disease activity parameters (ESR, CRP, DAS28, SW28, TEN28), antibody status (RF positive/negative; antiCCP positive/negative), and RTG stages in RA group (data not shown).

\section{DISCUSSION}

In the present study we examined SNPs at the -607 and -656 positions of the $I L-18$ gene in the patients with RA, in relation to disease susceptibility, activity and severity.

We found a significant difference in between RA patients and the control group in the distribution of heterozygous
Table 2

ALLELIC AND GENOTYPIC FREQUENCIES OF $I L$ - 18 GENE POLYMORPHISMS IN LATVIAN PATIENTS WITH RA AND CONTROLS

\begin{tabular}{lcc|c}
\hline & RA, $\mathrm{n}(\%)$ & Controls, $\mathrm{n}(\%)$ & $P$-value \\
\hline IL-18-656G/T & & & \\
Genotypes & $\mathrm{n}=104$ & $\mathrm{n}=237$ & \\
GG/GT/TT & $37(35.6) / 58$ & $99(41.8) / 105$ & 0.116 \\
& $(55.8) / 9(8.7)$ & $(44.3) / 33(13.9)$ & \\
& & & \\
Alleles & $2 \mathrm{n}=208$ & $2 \mathrm{n}=474$ & $0.931 *$ \\
G/T & $132(63.5) / 76$ & $303(63.9) / 171$ & \\
& $(36.5)$ & $(36.1)$ & 0.102 \\
IL-18-607C/A & & & \\
Genotypes & $\mathrm{n}=104$ & $\mathrm{n}=237$ & \\
CC/CA/AA & $37(35.6) / 58$ & $100(42.2) / 104$ & \\
& $(55.8) / 9(8.7)$ & $(43.9) / 33(13.9)$ & \\
& & & \\
Alleles & $2 \mathrm{n}=208$ & $2 \mathrm{n}=474$ & \\
C/A & $132(63.5) / 76$ & $304(64.1) / 170$ & $(35.9)$ \\
& $(36.5)$ & &
\end{tabular}

Values are given as number $(\%)$

Odds ratio and the confidence interval at the $95 \%$ confidence level is indicated as OR and $95 \% \mathrm{CI}$, respectively

*OR, 95\%CI 0.986, 0.78-1.25

**OR, 95\%CI 1.02, 0.81-1.29

T a ble 3

ALLELIC AND GENOTYPIC FREQUENCIES OF $I L-18$ GENE POLYMORPHISMS IN LATVIAN WOMEN WITH RA AND CONTROLS

\begin{tabular}{lcc|c}
\hline & RA, $\mathrm{n}(\%)$ & Controls, $\mathrm{n}(\%)$ & $P$-value \\
\hline IL-18-656G/T & \multicolumn{3}{c}{} \\
Genotypes & $\mathrm{n}=89$ & $\mathrm{n}=191$ & \\
GG/GT/TT & $31(34.8) / 51$ & $79(41.4) / 85$ & 0.097 \\
& $(57.3) / 7(7.9)$ & $(44.5) / 27(14.1)$ & \\
Alleles & $2 \mathrm{n}=178$ & $2 \mathrm{n}=382$ & \\
G/T & $113(63.5) / 65$ & $243(63.6) / 139$ & $1.000^{*}$ \\
& $(36.5)$ & $(36.4)$ & \\
IL-18-607C/A & & & \\
Genotypes & $\mathrm{n}=89$ & $\mathrm{n}=191$ & 0.084 \\
CC/CA/AA & $31(34.8) / 51$ & $80(41.9) / 84$ & \\
& $(57.3) / 7(7.9)$ & $(44.0) / 27(14.1)$ & \\
Alleles & $2 \mathrm{n}=178$ & $2 \mathrm{n}=382$ & $0.925^{* *}$ \\
C/A & $113(63.5) / 65$ & $244(63.9) / 138$ & \\
& $(36.5)$ & $(36.1)$ &
\end{tabular}

Values are given as number $(\%)$

Odds ratio and the confidence interval at the $95 \%$ confidence level is indicated as OR and $95 \% \mathrm{CI}$, respectively

*OR, 95\%CI 1.00, 0.74-1.28

**OR, 95\%CI 1.01, 0.79-1.30

versus homozygous genotypes. A significant difference was also found when only the respective women groups were examined. Reports evaluating the role of $I L-18$ promoter 
Table 4

GENOTYPIC FREQUENCIES OF IL-18 GENE POLYMORPHISMS IN LATVIAN PATIENTS WITH RA AND CONTROLS

\begin{tabular}{l|c|c|c|c}
\hline \multicolumn{1}{c|}{ Genotypes } & RA, n $(\%)$ & $\begin{array}{c}\text { Controls, } \mathrm{n} \\
(\%)\end{array}$ & $\begin{array}{c}P \text {-value } \\
\left(\chi^{2}\right)\end{array}$ & OR, 95\%CI \\
\hline IL-18-656G/T & & & & \\
GTvs.GG+TT & $58(55.8) / 46$ & $105(44.3) / 132$ & 0.060 & $1.37,100-1.90$ \\
GTvs.TT & $(44.2)$ & $(55.7)$ & & \\
& $58(86.6) / 9$ & $105(76.1) / 33$ & 0.098 & $1.66,0.90-3.07$ \\
GT+TTvs.GG & $(13.4)$ & $(23.9)$ & & \\
& $67(64.4) / 37$ & $138(58.2) / 99$ & 0.337 & $1.20,0.86-1.68$ \\
& $(35.6)$ & $(41.8)$ & &
\end{tabular}

IL-18-607C/A

$\begin{array}{lcccc}\text { CAvs.CC+AA } & 58(55.8) / 46 & 104(43.9) / 133 & 0.046 & 1.39,1.01-1.93 \\ & (44.2) & (56.1) & & \\ \text { CAvs.AA } & 58(86.6) / 9 & 104(75.9) / 33 & 0.097 & 1.67,0.90-3.09 \\ & (13.4) & (24.1) & & \\ \text { CA+AAvs.CC } & 67(64.4) / 37 & 137(57.8) / 100 & 0.281 & 1.23,0.87-1.71 \\ & (35.6) & (42.2) & & \end{array}$

Values are given as number $(\%)$

Odds ratio and the confidence interval at the $95 \%$ confidence level is indicated as OR and $95 \% \mathrm{CI}$, respectively

Table 5

GENOTYPIC FREQUENCIES OF IL-18 GENE POLYMORPHISMS IN LATVIAN WOMEN WITH RA AND CONTROLS

\begin{tabular}{|c|c|c|c|c|}
\hline Genotypes & $\mathrm{RA}, \mathrm{n}(\%)$ & $\begin{array}{c}\text { Controls, } \mathrm{n} \\
(\%)\end{array}$ & $\begin{array}{c}P \text {-value } \\
\left(\chi^{2}\right)\end{array}$ & $\mathrm{OR}, 95 \% \mathrm{CI}$ \\
\hline \multicolumn{5}{|l|}{ IL-18-656G/T } \\
\hline GT vs. GG+TT & $\begin{array}{c}51(57.3) / 38 \\
(42.7)\end{array}$ & $\begin{array}{c}85(44.5) / 106 \\
(55.5)\end{array}$ & 0.054 & $1.42,1.00-2.01$ \\
\hline GT vs. TT & $\begin{array}{c}51(87.9) / 7 \\
(12.1)\end{array}$ & $\begin{array}{c}85(75.9) / 27 \\
(24.1)\end{array}$ & 0.071 & $1.82,0.91-3.65$ \\
\hline GT+TT vs. GG & $\begin{array}{c}58(65.2) / 31 \\
(34.8)\end{array}$ & $\begin{array}{c}112(58.6) / 79 \\
(41.4)\end{array}$ & 0.358 & $1.21,0.84-1.74$ \\
\hline \multicolumn{5}{|l|}{ IL-18-607C/A } \\
\hline $\mathrm{CA}$ vs. $\mathrm{CC}+\mathrm{AA}$ & $\begin{array}{c}51(57.3) / 38 \\
(42.7)\end{array}$ & $\begin{array}{c}84(44.0) / 107 \\
(56.0)\end{array}$ & 0.041 & $1.44,1.02-2.04$ \\
\hline CA vs. AA & $\begin{array}{c}51(87.9) / 7 \\
(12.1)\end{array}$ & $\begin{array}{c}84(75.7) / 27 \\
(24.3)\end{array}$ & 0.070 & $1.84,0.92-3.68$ \\
\hline $\mathrm{CA}+\mathrm{AA}$ vs. $\mathrm{CC}$ & $\begin{array}{c}58(65.2) / 31 \\
(34.8)\end{array}$ & $\begin{array}{c}111(58.1) / 80 \\
(41.9)\end{array}$ & 0.295 & $1.23,0.85-1.77$ \\
\hline
\end{tabular}

Values are given as number $(\%)$

Odds ratio and the confidence interval at the $95 \%$ confidence level is indicated as OR and $95 \% \mathrm{CI}$, respectively

polymorphisms in RA patients have shown variable results for different SNPs. Sivalingam et al (2003) found that controls had significantly higher frequency of the AA genotype at position -607 when compared to RA patients and concluded that the AA genotype at position -607 is associated with a protective effect against development of RA in Chinese individuals. Rueda et al. (2005) observed no statistically significant differences between RA patients and controls in allelic and genotypic frequencies of $-607 \mathrm{C} / \mathrm{A}$ and
-137C/G IL-18 promoter polymorphisms. In addition, no association was found with the haplotypes inferred by the two polymorphisms and RA susceptibility. RA patients were stratified according to sex, age at the onset of the disease rheumatoid factor status, and extraarticular manifestations and no association was found with these polymorphisms. Therefore, the conclusion is that studied polymorphisms within the IL-18 promoter region do not play a major role in RA predisposition.

Gracie et al. (2005) found that the $-607 \mathrm{C} /-137 \mathrm{C}$ haplotype was more prevalent in Caucasian RA patients than in a control group and concluded that SNP of both positions contribute to the genetic background of RA pathogenesis.

Lee et al. (2007) reported a significantly higher frequency of the 105A allele of the IL-18-105A/C SNP in Chinese rheumatoid arthritis patients compared with controls. The relative risk of rheumatoid arthritis was stronger in 105A homozygotes. Sugiura et al. (2006) showed that 12 SNP within the promoter region of the $I L-18$ gene were associated with susceptibility to juvenile idiopathic arthritis (JIA) in Japanese patients. There was a strong association between the diplotype configuration of S01/S01 of the $I L-18$ gene and JIA. T at position -656, A at position -607 , and $\mathrm{G}$ at position -137 were the components of haplotype S01.

In the recent study by Pawlik et al. (2009), where seven IL18 gene SNPs were studied, no significant differences were found in the distributions of the genotypes except for rs360722 and haplotypes between RA patients and a control group. Age at RA diagnosis was lower in carriers of the -607 CC and rs187238 GG genotypes. Erosive disease was diagnosed more frequently in patients with the $-607 \mathrm{CC}$ and AC genotypes than in AA homozygotes.

A possible explanation for the discordant results could be linkage with other polymorphisms within the gene or within other genes; another one might be the variation of genetic susceptibility between ethnic groups (Burchard et al., 2003). Allelic heterogeneity exists between ethnic groups, and different variations within the same gene can contribute to disease risk (Colhoun et al., 2003).

It is well known that gene promoter polymorphisms can affect the level of protein production. The gene sequence can be associated with a cytokine phenotype. Homozygotes for the high-producer allele are the highest producers of the cytokine, homozygotes for the low-producer allele are the lowest producers of the cytokine and heterozygotes are intermediate. On the other hand, we can assume that homozygotes for the allele are the lowest producers of the cytokine and heterozygotes are the highest producers of the cytokine. Khripko et al. (2008) studied distribution of $I L-18$ allele variants at positions $-607 \mathrm{C} / \mathrm{A}$ and $-137 \mathrm{G} / \mathrm{C}$ in healthy donors from Siberia and the influence of these allele variants on the level of IL-18 production by peripheral blood mononuclear cells (PBMCs). The authors found that lipopolysaccharide (LPS)-stimulated production of IL-18 by PBMC from healthy donors was significantly greater in 
those carrying the CA genotype at the -607 position, compared with donors with the $-607 \mathrm{CC}$ genotype.

RA is one of many autoimmune diseases that is predominant in women, as it has a female-to-male ratio $2: 1$ to $3: 1$. Sex hormones can have significant effects on the cells known to participate in RA. However, the specific mechanisms responsible for increased susceptibility to RA in women are uncertain. Padyukov et al. (2004) showed an association of IL10 - 1087 genotypes in woman with RA compared with men and controls. The observed difference in frequencies of alleles and genotypes of the $I L-18$ gene in positions -607 and -656 between RA patients and the control group in women suggests that RA in woman is a different disease subset. Further studies are needed and using a larger patient group, covering all rheumatology departments in Latvia. Patients should be enrolled based on the same inclusion criteria and with similar phenotypic data as used in the present study.

In conclusion, heterozygous states CA and GT at positions -607 and -656 , respectively, of IL-18 gene may influence susceptibility to RA. More studies on a larger patient group is needed, to explore this association in Latvian population. On the basis of the investigated $I L-18$ polymorphisms, female patients with RA seem to represent a separate disease subgroup.

\section{REFERENCES}

Arnett, F.C., Edworthy, S.M., Bloch, D.A., McShane, D.J., Fries, J.F., Cooper, N.S., Healey, L.A., Kaplan, S.R., Liang, M.H., Luthra, H.S. (1988). The American Rheumatism Association 1987 revised criteria for the classification of rheumatoid arthritis. Arthritis Rheum., 31(3), 315-324.

Burchard, E.G., Ziv, E., Coyle, N., Gomez, S.L, Tang, H., Karter, A.J., Mountain, J.L., Pérez-Stable, E.J., Sheppard, D., Risch, N. (2003). The importance of race and ethnic background in biomedical research and clinical practice. New Engl. J. Med., 348(12), 1170-1175.

Colhoun, H.M., McKeigue, P.M., Davey-Smith, G. (2003). Problems of reporting genetic associations with complex outcomes. Lancet, 361, 865-872.

Dai, S.M., Nishioka, K., Yudoh, K. (2004). Interleukin (IL) 18 stimulates osteoclast formation through synovial T cells in rheumatoid arthritis: Comparison with IL1 beta and tumour necrosis factor alpha. Ann. Rheum. Dis., 63(11), 1379-1386.

Dinarello, C.A. (1999) IL-18: A TH1-inducing, proinflammatory cytokine and new member of the IL-1 family. J. Allergy Clin. Immunol., 103(1 Pt 1), $11-24$.

Dinarello, C.A., Novick, D., Puren, A.J., Fantuzzi, G., Shapiro, L., Mühl, H., Yoon, D. Y., Reznikov, L.L., Kim, S.H., Rubinstein, M. (1998). Overview of interleukin-18: More than an interferon-gamma inducing factor. $J$. Leukoc. Biol., 63(6), 658-664.

Feldmann, M., Brennan, F.M., Maini, R.N. (1996). Role of cytokines in rheumatoid arthritis. Annu. Rev. Immunol., 14, 397-440.

Gardella, S., Andrei C., Costigliolo, S., Poggi, A., Zocchi, M.R., Rubartelli, A. (1999). Interleukin-18 synthesis and secretion by dendritic cells are modulated by interaction with antigen-specific T cells. J. Leukoc. Biol., 66(2), 237-241.

Giedraitis, V., He, B., Huang, W.X., Hillert, J. (2001). Cloning and mutation analysis of the human $I L-18$ promoter: A possible role of polymorphisms in expression regulation. J. Neuroimmunol., 112(1-2), 146-152.
Gracie, J.A., Forsey, R.J., Chan, W.L., Gilmour, A., Leung, B.P., Greer, M.R., Kennedy, K., Carter, R., Wei, X.Q., Xu, D., Field, M., Foulis, A., Liew, F.Y., McInnes, I.B. (1999). A proinflammatory role for IL-18 in rheumatoid arthritis. J. Clin. Invest., 104 (10), 1393-1401.

Gracie, J.A, Koyama, N., Murdoch, J., Field, M., McGarry, F., Crilly, A., Schobel, A., Madhok, R., Pons-Kühnemann, J., McInnes, I.B., Möller, B. (2005). Disease association of two distinct interleukin-18 promoter polymorphisms in Caucasian rheumatoid arthritis patients. Genes Immun., 6(3), 211-216.

Joosten, L.A., Radstake, T.R., Lubberts, E., van den Bersselaar, L.A., van Riel, P.L., van Lent, P.L., Barrera, P., van den Berg, W.B. (2003). Association of interleukin-18 expression with enhanced levels of both interleukin-1beta and tumor necrosis factor alpha in knee synovial tissue of patients with rheumatoid arthritis. Arthritis Rheum., 48(2), 339-347.

Khripko, O.P., Sennikova, N.S., Lopatnikova, J.A., Khripko, J.I., Filipenko, M.L., Khrapov, E.A., Gelfgat, E.L., Yakushenko, E.V., Kozlov, V.A., Sennikov, S.V. (2008). Association of single nucleotide polymorphisms in the $I L-18$ gene with production of IL-18 protein by mononuclear cells from healthy donors. Mediators Inflamm., DOI: 10.1155/2008/309721.

Lee, C.C., Lin, W.Y., Wan, L., Tsai, Y., Lin, Y.J., Tsai, C.H., Huang, C.M., Tsai, F.J. (2007). Interleukin-18 gene polymorphism, but not interleukin-2 gene polymorphism, is associated with rheumatoid arthritis. Immunogenetics, 59(6), 433-439.

Morel, J.C., Park, C.C., Kumar, P., Koch, A.E. (2001). Interleukin-18 induces rheumatoid arthritis synovial fibroblast $\mathrm{CXC}$ chemokine production through NFkappaB activation. Lab. Invest., 81(10), 1371-1383.

Morel, J.C., Park, C.C., Zhu, K., Kumar, P., Ruth, J.H., Koch, A.E. (2002). Signal transduction pathways involved in rheumatoid arthritis synovial fibroblast interleukin-18-induced vascular cell adhesion molecule-1 expression. J. Biol. Chem., 277(38), 34679-34691.

Nolan, K.F., Greaves, D.R., Waldmann, H. (1998). The human interleukin 18 gene $I L-18$ maps to $11 \mathrm{q} 22.2-\mathrm{q} 22.3$, closely linked to the $D R D 2$ gene locus and distinct from mapped IDDM loci. Genomics, 51(1), 161-163.

Okamura, H., Tsutsi, H., Komatsu, T., Yutsudo, M., Hakura, A., Tanimoto, T., Torigoe, K., Okura, T., Nukada, Y., Hattori, K. (1995). Cloning of a new cytokine that induces IFN-gamma production by T cells. Nature, 378(6552), 88-91.

Padyukov, L., Hytonen, A.M., Smolnikova, M., Hahn-Zoric, M., Nilsson, N., Hanson, L. A., Tarkowski, A., Klareskog, L. (2004). Polymorphism in promoter region of $I L 10$ gene is associated with rheumatoid arthritis in women. J. Rheumatol., 31(3), 422-425.

Park, C.C., Morel, J.C., Amin, M.A., Connors, M.A., Harlow, L.A., Koch, A.E. (2001). Evidence of IL-18 as a novel angiogenic mediator. $J$. Immunol., 167(3), 1644-1653.

Pawlik, A., Kurzawski, M., Drozdzik, M., Dziedziejko, V., Safranow, K., Herczynska, M. (2009). Interleukin-18 gene (IL-18) promoter polymorphisms in patients with rheumatoid arthritis. Scand. J. Rheumatol., 38(3), 159-165.

Petrovic-Rackov, L., Pejnovic, N. (2006). Clinical significance of IL-18, IL-15, IL-12 and TNF-alpha measurement in rheumatoid arthritis. Clin. Rheumatol., 25(4), 448-452.

Pincus, T., Larsen, A., Brooks, R.H., Kaye, J., Nance, E.P., Callahan, L.F. (1997). Comparison of 3 quantitative measures of hand radiographs in patients with rheumatoid arthritis: Steinbrocker stage, Kaye modified Sharp score, and Larsen score. J. Rheumatol., 24(11), 2106-2112.

Prevoo, M. L., van 't Hof, M.A., Kuper, H.H., van Leeuwen, M.A., van de Putte, L.B., van Riel, P.L. (1995). Modified disease activity scores that include twenty-eight-joint counts. Development and validation in a prospective longitudinal study of patients with rheumatoid arthritis. Arthritis Rheum., 38(1), 44-48.

Rooney, T., Murphy, E., Benito, M., Roux-Lombard, P., FitzGerald, O., Dayer, J.M., Bresnihan, B. (2004). Synovial tissue interleukin-18 expression and the response to treatment in patients with inflammatory arthritis. Ann. Rheum. Dis., 63(11), 1393-1398. 
Rueda, B., Gonzalez-Gay, M.A., Mataran, L., Lopez-Nevot, M.A., Martin, J. (2005). Interleukin-18-promoter polymorphisms are not relevant in rheumatoid arthritis. Tissue Antigens, 65(6), 544-548.

Sivalingam, S.P., Yoon, K.H., Koh, D.R., Fong, K.Y. (2003). Single-nucleotide polymorphisms of the interleukin-18 gene promoter region in rheumatoid arthritis patients: Protective effect of AA genotype. Tissue Antigens, 62(6), 498-504.

Sugiura, T., Maeno, N., Kawaguchi, Y., Takei, S., Imanaka, H., Kawano, Y., Terajima-Ichida, H., Hara, M., Kamatani, N. (2006). A promoter haplotype of the interleukin-18 gene is associated with juvenile idiopathic arthritis in the Japanese population. Arthritis Res. Ther., 8(3), R60.

Tanaka, M., Harigai, M., Kawaguchi, Y., Ohta, S., Sugiura, T., Takagi, K., Ohsako-Higami, S., Fukasawa, C., Hara, M., Kamatani, N. (2001). Mature form of interleukin 18 is expressed in rheumatoid arthritis synovial tissue and contributes to interferon-gamma production by synovial T cells. $J$. Rheumatol., 28(8), 1779-1787.

Westphal, E., Herzberg, M., Neumann, I., Beibei, L., Pilowski, C., Li, C., Werdan, K., Loppnow, H. (2006). Neutrophils process interleukin-1beta and interleukin-18 precursors in a caspase-1-like fashion-processing is inhibited by human vascular smooth muscle cells. Eur. Cytokine Netw., 17(1), 19-28.

Yamamura, M., Kawashima, M., Taniai, M., Yamauchi, H., Tanimoto, T., Kurimoto, M., Morita, Y., Ohmoto, Y., Makino, H. (2001). Interferon-gamma-inducing activity of interleukin-18 in the joint with rheumatoid arthritis. Arthritis Rheum., 44(2), 275-285.

Yamaoka-Tojo, M., Tojo, T., Masuda, T., Machida, Y., Kitano, Y., Kurosawa, T., Izumi, T. (2003). C-reactive protein-induced production of interleukin-18 in human endothelial cells: a mechanism of orchestrating cytokine cascade in acute coronary syndrome. Heart Vessels, 18(4), 183-187.

Received 22 April 2011

\section{INTERLEIKĪNA 18 GĒNA PROMOTERA POLIMORFISMI LATVIJAS SLIMNIEKIEM AR REIMATOĪDO ARTRĪTU}

Interleikīns 18 (IL-18) ir proinflamatorais citokīns, kas iesaistīts reimatoīdā artrīta (RA) patoğenēzē. Dati par to, vai šì interleikīna promotera polimorfismi var būt neatkarīgi RA ǵenētiskie markieri, ir pretrunīgi. Šì pētījuma mērkis bija noteikt, vai $I L-18$ gēna promotera polimorfismi -607 (rs 1946519) un -656 (rs 1946518) pozīijā ir saistīti ar RA un tā īpatnībām Latvijas populācijā. Mēs izmeklējām 105 pacientus ar diagnosticētu RA saskaņā ar Amerikas reimatoloğijas koledžas diagnostiskajiem kritērijiem. Veselo kontroḷu DNS un fenotipiskie dati iegūti no (Latvijas) Valsts iedzīvotāju genoma datu bāzes. Genotipi noteikti ar tiešu sekvenēšanu. Polimorfismi pētīti un alēḷu un genotipu biežumi salīdzināti starp RA slimniekiem un kontrolgrupu. $P$ vērtība mazāka par 0,05 pieņemta par statistiski būtisku. Mūsu pētījumā neatradām būtiskas atšķirības starp alēḷu un genotipu biežumu starp RA slimniekiem un kontrolgrupu. Tendence uz asociāciju konstatēta starp IL-18-607C/A un -656G/T genotipiem sievietēm un kontrolgrupu $(P=0,084$ un 0,097$)$. Heterozigotiskus genotipus -607CA un -656GT novēroja biežāk RA grupā, nekā kontrolgrupā $(P=0,046, P=0,060)$. Atšķirības novēroja, salīdzinot heterozigotisku genotipu -607CA un -656GT arī sievietēm $(P=0,041, P=0,054)$. Secinājumi: heterozigotiskie genotipi $-607 C A$ un -656GT IL18 gēna promoterā var ietekmēt RA uzṇēmību. Pamatojoties uz izmeklētiem IL18 polimorfismiem, RA slimnieces, škiet, pārstāv atsevišķu slimības apakšgrupu. 